\title{
Connected teaching and learning: The uses and implications of connectivism in an online class
}

\author{
John Barnett, Vance McPherson, and Rachel M. Sandieson \\ Western University, Canada
}

\begin{abstract}
An instructor tried using connectivism to teach an online graduate Education course called Teaching in a Virtual World. As a way to embody the many connections inherent in the group, all members of the class created and taught modules of their own choosing to each other. The instructor and two former students reflected together online in depth about their experience and coded their joint understandings. Schwab's commonplaces of curriculum emerged in the data, demonstrating that it is still current. They found that the course, however, was not completely connectivist due to limitations emanating from its operation within a traditional university setting.
\end{abstract}

\section{Introduction}

This article describes a retrospective study of an online course within which we, the three co-authors participated. Our study was centred on connectivism in practice, a fairly new learning theory. Hence, we start our discussion with a history and description of the theory and its implications before reporting our results and their implications.

\section{Emergence of connectivism}

Online learning has a long history reaching back to the first online technologies such as electronic mail and computer conferencing systems. Throughout the early development of new technologies in education, those in the field faced the bias that online learning was somehow not as good as face-to-face learning. By the late 1990s, researchers started to develop theoretical understandings of learning delivered through new technologies. One framework described the organization of various courses as "content+support", "wrap around" or "integrative" (Mason, 1998) or they described what they were doing as computer mediated communication (Rapaport, 1991) or computer supported collaborative learning. As time went on, a number of researchers created more complete theoretical models such as the community of inquiry framework (Garrison \& Vaughan, 2008) and the technological pedagogical and content knowledge (TPACK) framework (Koehler \& Mishra, 2008) to explain various facets of these new technologies in education.

Today, as online education becomes ubiquitous, instructors employ many different philosophical approaches to learning from behaviourism, cognitivism and constructivism; approaches that attempt to explain, amongst other things, how learning occurs in face-to-face environments (such as classrooms), or at least in situations with clear authority-student dynamics (such as learning from books). We will refer to these approaches to teaching and learning as the canonical approaches or models in this paper. Each of the canonical models originated before the advent of the digital age in education.

As online learning evolved and facilitating technologies emerged, some authors posited that none of the three canonical approaches was sufficient to describe new types of learning that were happening in the online milieu. Students with the ability to direct their own learning, pulling information from a variety of human and other resources, were not necessarily operating in behaviorist or cognitivist frameworks. Furthermore, their learning had more to do with the integration and critical analysis of, and contribution to, disparate resources than simple existential constructions of meaning. So constructivism could not precisely explain such learning, either. Therefore, there was a need to develop a new approach; one that took into consideration experiences gained in this emerging virtual landscape.

It was in light of new technological interaction that connectivism emerged much more like a bird breaking out of its shell than an explicit creation of theorists. They simply described what they were seeing. Like the infant bird, many functioning systems had to be in place before the emergence could occur successfully. 
In the first electronic computers, memory was encapsulated by the states (ON/OFF) of multiple programmed switches in electronic circuits. The development of computer networks like DARPA and eventually the World Wide Web created a need to conceptualize the interactions that occurred between their servers. At a similar time, neurophysiologists came to the notion of neural networks (Hopfield, 1982) with the same on/off states for neural transmission which relate to complex system theories that describe the relationships of parts to the whole over long periods of time and alluded to by Sibani and Jensen (2013). Approaches from artificial intelligence, neuroscience and philosophy of mind created the notion that interconnected networks of more simple parts can result in mental phenomena. This was termed connectionism. Siemens (2005) opined that connectivism evolved from earlier connectionist ideas that situated knowledge as nodes in a network without any meaning of their own (Bereiter, 1991).

Actor-network theory (ANT) was another of these efforts. ANT is a theory of the interactions and products of networks. In ANT, a bit of knowledge in a network is comparable to Bruno Latour's concept of the immutable mobile (Fenwick, 2010). That is, it is an artefact such as an essay, graphic, sound or other data within a network that allows individuals to perceive more than their own senses (Gorman, 2001). This notion of nodes within the network was key to thinking about learning within a network.

However, learning within a network requires that bits of knowledge not be mobile since they are contextual and bits cannot drop into another network without being modified or without modifying the new network. In connectivism, the imposition of a new artefact into a network is the addition of a new node within the network.

\section{Overview of connectivism}

For our purposes it is not important to define connectivism as a theoretical model, framework or theory. Its implications and functionality are the keys to its usefulness. We describe it here for readers less familiar with the notion.

Connectivism is an epistemological approach grounded in the interactions within networks (Downes, 2012a) both inside the individual mind (Spitzer, 1999) and outside to the world, rather than to the individual memory of what to do (behaviourism), what to think (cognitivism) or how to make meaning (constructivism). It is becoming more influential and contentious of late due to its use as the epistemological basis for massive open online courses (MOOCs) (Bell, 2011). Indeed, some authors (Tschofen \& Mackness, 2012) describe a conflation of MOOCs and connectivism making it important to reiterate that connectivism represents a novel epistemology that has deep implications for our understanding of the ways that learning happens and is not itself contingent upon social or technological innovation (Downes, 2012b).

Interestingly, if we think of it as an educational framework, connectivism incorporates many of the understandings of the canonical approaches. We can glimpse a facet of behaviourism in the connectivist requirement that to know something, one must be able to do it; it shares the notions of neural networks with cognitivism; and it supports the group and community notions of social constructivism and transformational teaching (Slavich \& Zimbardo, 2012). However, it goes beyond all three in that it is learner-driven (Marcum, 2006). It also explains why disparate teaching strategies from peer assessment to problem-based learning, and student leadership seem to work well. Thus, as an approach to education, if not a formal theory to teachers, it is both novel and well known to them at the same time.

Ireland (2007, para 7) the original creator of a wiki page in a course on technology enhanced learning environments compared the four approaches: 


\begin{tabular}{|l|l|l|l|l|l|}
\hline & Questions & Behaviourism & Cognitivism & Constructivism & Connectivism \\
\hline 1. & $\begin{array}{l}\text { How does learning } \\
\text { occur? }\end{array}$ & $\begin{array}{l}\text { Black box-observ- } \\
\text { able behaviour main } \\
\text { focus }\end{array}$ & $\begin{array}{l}\text { Structured, computa- } \\
\text { tional }\end{array}$ & $\begin{array}{l}\text { Social, meaning cre- } \\
\text { ated by each learner } \\
\text { (personal) }\end{array}$ & $\begin{array}{l}\text { Distributed within a } \\
\text { network, social, tech- } \\
\text { nologically enhanced, } \\
\text { recognizing and inter- } \\
\text { preting patterns }\end{array}$ \\
\hline 2. & $\begin{array}{l}\text { What factors influence } \\
\text { learning? }\end{array}$ & $\begin{array}{l}\text { Nature of reward, pun- } \\
\text { ishment, stimuli }\end{array}$ & $\begin{array}{l}\text { Existing schema, pre- } \\
\text { vious experiences }\end{array}$ & $\begin{array}{l}\text { Engagement, partici- } \\
\text { pation, social, cultural }\end{array}$ & Diversity of network \\
\hline 3. & $\begin{array}{l}\text { What is the role of } \\
\text { memory? }\end{array}$ & $\begin{array}{l}\text { Memory is the hard- } \\
\text { wiring of repeated } \\
\text { experiences-where } \\
\text { reward and punish- } \\
\text { ment are most influ- } \\
\text { ential }\end{array}$ & $\begin{array}{l}\text { Encoding, storage, } \\
\text { retrieval }\end{array}$ & $\begin{array}{l}\text { Prior knowledge } \\
\text { remixed to current } \\
\text { context }\end{array}$ & $\begin{array}{l}\text { Adaptive patterns, } \\
\text { representative of cur- } \\
\text { rent state, existing in } \\
\text { networks }\end{array}$ \\
\hline 4. & $\begin{array}{l}\text { How does transfer } \\
\text { occur? }\end{array}$ & $\begin{array}{l}\text { Stimulus, response } \\
\text { nections }\end{array}$ & $\begin{array}{l}\text { Duplicating knowl- } \\
\text { edge constructs of } \\
\text { "knower" }\end{array}$ & Socialization & $\begin{array}{l}\text { Connecting to (add- } \\
\text { ing) nodes }\end{array}$ \\
\hline 5. & $\begin{array}{l}\text { Types of learning } \\
\text { best explained by this } \\
\text { theory? }\end{array}$ & Task-based learning & $\begin{array}{l}\text { Reasoning, clear } \\
\text { objectives, problem } \\
\text { solving }\end{array}$ & $\begin{array}{l}\text { Social, vague ("ill } \\
\text { defined") }\end{array}$ & $\begin{array}{l}\text { Complex learning, } \\
\text { rapid changing core, } \\
\text { diverse knowledge } \\
\text { sources }\end{array}$ \\
\hline
\end{tabular}

Figure 1. Comparison of four approaches to learning (from Ireland, 2007).

Connectivism not only builds on the earlier notion of connectionism from computer science but also on the idea of situated cognition (Lave \& Wenger, 1991), that knowledge occurs not only in the minds of individuals; but rather, is supra- and trans-individual and also exists within and between groups. Its heritage also includes that of collective intelligence (Levy, 1997) which is the idea that through the use of collaborative technologies people can carry out a task as if the group were a single organism rather than individual agents (Smith, 1995). Based on such thinking, we hold the view that the collective knowing of a group of people is greater than any one individual's knowledge. Moreover, group knowledge is knowledge not simply in symbolic or poetic ways but in literal ways, in that it can be defined as the set of connections formed by action or experience (Downes, 2007). Knowledge is inherently distributed and relies on the presence of networks (Siemens, 2005) without which it could not exist. Dunaway (2011) concurs with Downes (2012b) that "knowledge" is emergent from an individual's learning network as connections are recognized, that is, "learning occurs as connections are made" (Dunaway, 2011, p. 676).

In spite of growing acknowledgement of connectivism as a useful approach to technology-enabled learning (Cormier, 2008), some authors have leveled considerable criticism at it. Bell (2011) and others have argued on technical grounds that it is merely a phenomenon or a curriculum, rather than a novel learning theory. Kop (2008) as well as Anderson and Dron (2011) believe that it is very similar to the older and more established actor-network theory. Wade (2012) criticized it by asking where the knowledge came from to create networks in the first place, the sort of argument often used by creationists to discount evolutionary theory of brain development. We hold the view that connectivism is an important new epistemology for education, and in this section, we will briefly examine our rationale for this position.

The three canonical and widely acknowledged models of learning share some fundamental assumptions about learning and knowledge. With some exceptions, such as radical constructivism, there is an assumption that there is a relationship between personal knowledge and behaviour, the end result of learning. Learning becomes the process of acquiring that knowledge. The locus of learning is the student. Behaviourists see learning as possible change in an individual's behaviour based upon experience; cognitivists see learning as potential change in an individual's thinking and other brain functions as a result of experience; and constructivists see learning as the individual's personal or social construction of meaning through experience. Many, if not most, online courses today support constructivist principles by making students' interactions with other students and their instructor a central element of the student experience.

Connectivism acknowledges the value of experience, but rejects the notion implicit in the other approaches that learning can occur in the absence of a network. Indeed, individual learning is the 
formation, and growth, of neural connections in the networks of one's own brain. While learning occurs at the level of the individual, knowledge is the negotiation through which that learning takes place. Indeed, non-human agents may be a part of the overall phenomenon that defines knowledge. Thus, people and non-human agents may learn by both constructing and traversing epistemic and electronic networks (Downes, 2007) which are, in turn, constructed and traversed by people and non-human agents simultaneously. This type of learning cannot be modelled by any canonical learning model, each of which regards the human brain as the necessary and sufficient container of knowledge.

Another key difference between the three canonical approaches and connectivism is its implication about the structure of curriculum design. In learning experiences based on connectivism, the structure and assessments tend to be emergent from the experience itself, as opposed to behaviourist or cognitivistinspired courses where the structure and assessments are clear. It also differs from constructivist-inspired courses, where structure and assessments tend to be scaffolded by the instructor. Connectivism is therefore disruptive to theories that emphasize the importance of clear learning goals (Anderson \& Dron, 2011). Interestingly, these authors use this argument as a part of their rationale for dismissing connectivism as a theory of teaching. However, in our opinion, the point demonstrates that from a connectivist point of view, there is no semantic difference between a model of teaching and a model of learning. As Ireland (2007, para 9) noted:

Importantly and practically, connectivism's recognition of the meteoric and chaotic explosion of knowledge, and its emphasis on the network links available to access that knowledge, gives educators and educational designers the impetus and the framework to move learners into advanced levels of accomplishment. The question of whether connectivism is a theory or a curricular concept can wait for tomorrow. Educators need to use it today.

\section{Implications of connectivism}

Perhaps the most profound pedagogical implication of connectivism is that retention of information is no longer important. What is important is the development of rich and powerful connections that are accessible quickly and easily whenever someone wants to use them. Learning becomes the critical recognition of connections that change the network itself, simultaneously adding new connections, potentially in the absence of an instructor or authority.

Much like the place where two strands of a spider's web touch each other, every individual has a position, or node, within a wider web of knowing. The only flaw in the web metaphor is that learning is not static and necessarily involves creating new threads to other points on the web. The more and stronger strands you have, the better and more resilient your web becomes. It also goes beyond the web analogy in prioritizing the strands. Connections to weak sources are far less valuable than connections to strong sources but weak connections or weak "ties"' (Granovetter, 1983) are more valuable than strong connections. It is through weak connections that we can add the most new perspectives to our node in the network.

We further argue that fast connections are also better than slow connections. One needs only to compare the experience of cross-referencing hypertext links in Wikipedia with the experience of cross-referencing ideas in an encyclopedia at the library to prove this point. We also suggest connectivism requires being current; if your connections no longer work then they have no more value. It does not mean that personal knowledge itself does not count, but that it loses value, from an educational perspective, when one cannot access it. Thus, we suggest that a corollary to connectivism is the necessity to ensure that links to older sources are not lost as new links are made. The world may know more every day, but it does so only if it holds onto its history.

Of course, connections are not always external to the individual. The brain itself is a network of neurons and the best neuroscientific understanding of brain function (Schunk, 2004) contends that memories are held within, and even defined by, particular constellations of neuronal connections (Rolls, 2008); thinking means accessing and activating one's neuronal circuits. The thinking of an individual is an internal form of connectivism; the more circuits you have and the better you can access those circuits, the easier you can recall memories and the better you can think. 
Obviously, some connections will not be as good as others. Therefore, we assume that individuals' learning requires the development of critical ability to analyze what counts as good connections. Someone who has made multiple connections but cannot discriminate among them does not have as valuable a network as someone who can logically prioritize some over others. According to Dunaway (2011), connectivism provides a framework for understanding how students learn, and good learning in turn involves critical evaluation and synthesis of connections. In other words, connectivism is a learning theory in and of itself, but to be an effective teaching theory, it must also incorporate metaliteracy (a framework for integrating multiple technologies and multiple literacy types) and transliteracy (the skill of being able to read, write and interact across a range of platforms) (Dunaway, 2011). Mackay and Jacobson (2011) elaborate that a more complex approach to information literacy is needed than simple skill development, i.e., how to access information from the Internet. Rather, participation in the accessing, evaluation and sharing of findings helps students to learn more about knowledge itself. This competency of metaliteracy as a teaching theory looks very much like connectivism as a learning theory and reinforces our position that in a truly connectivist framework, due to the distributed nature of knowledge and the role of the instructor as a co-participant, there is no semantic or phenomenological difference between connectivism as a teaching theory or learning theory.

The disruptive challenge of connectivism in education is its rhizomatic nature (Cormier, 2008). There can be no central source of knowledge for a connectivist course. The class as a whole democratically owns and can share the connections that, collectively, they have available. Together, all the participants (including the instructor) know more than the instructor alone. This position is a hard one to accept for those who have made a career out of "knowing more" and "knowing better" than their students. It is not that instructors' knowledge is valueless, but rather, teachers must learn to use the connections brought by their students and teach everyone how to evaluate the connections that are shared. Instructors can no longer hold the web of connections and dole it out to students as they see fit, but have to defend their own networks and explain the strength of their connections in dialogue with their students. Indeed, teaching becomes inseparable from learning as everyone in the class gains new connections. In other words, the power of knowing is stripped from instructors and placed in the hands of the whole class. The instructor must show why the connections they have made to understand their world in the past, should also work for the students in the present. As Siemens (2010) contends, the instructor's position shifts from one of control to one of influence. Teaching becomes the activity of facilitating connections within the overall class web. Teaching also becomes custodial, maintaining important connections of the past. Most of all, teaching becomes the process of helping students and society to critically examine connections in their courses and in their present and future lives.

If one examines the implications of connectivist thought it is apparent that it disrupts the current educational system that has student assessment at its core. It is difficult and perhaps impossible to know how many new connections that students have made, let alone their value. It may very well be that true connectivist courses are not possible within the frameworks of educational institutions as they now exist and hence why connectivism, when used, is disruptive.

\section{The project - a course inspired by connectivism}

\section{Course details}

It was within normal institutional constraints that a kind of connectivist course evolved in a Master of Education online program at a Canadian university. The course, Teaching in a Virtual World (TVW), was an elective that was previously taught a number of times by different instructors using a variety of different approaches.

In previous iterations, TVW instructors taught it more like a traditional online graduate course, using a more theoretical, less pragmatic stance. Instructors created the modules, gave students important articles to read and discuss online, and the students produced essays as their culminating activity. Depending upon the views of the instructor, the class discussed the virtual world in broader terms to encompass the effects of many new technologies, or reflected a more immersive approach. Students gave input and interacted with each other through the discussion boards and other venues. Instructors participated in the 
discussions to the extent that they felt necessary. For students, it can be assumed, the course was similar to many other online courses that were available.

In this iteration, one of the co-researchers [Barnett], the course instructor, took a different tactic and employed connectivism as the basis for teaching the course. In the course, 17 students were enrolled and along with the instructor that created a class of 18 participants. As a result of the instructor's connectivist leanings, each participant taught one module of the course. Most students chose a topic in which they had expertise or interest. However, in some cases, the instructor assigned the topic to students if they had not picked one for themselves.

Thus, there were 18 week-long modules in the ten-week term, organized by broad topic based on the needs and interest of individual students, from which each student had to choose ten to take.

Since the class size was greater than the number of weeks that the course was to run, some of the weeks were doubled up. So, for eight weeks there were two different modules offered. The instructor [Barnett] taught and moderated the first module, on online communication, to model teaching online to the entire class. [Sandieson], a student in the course, taught and moderated the second module on web 2.0 to the entire class. The remaining sixteen students [including McPherson] taught and moderated their modules to half the class each. The rest of the topics (see Table 1), which were occasionally taught more than once, included: Online collaboration, Online community, Internet safety, Online assessment, Time management, Academic dishonesty and simulation. In addition, some students with particular knowledge taught modules on: Second language acquisition, Tablet computing, Exceptional children and At-risk students.

Table 1

Course calendar

\begin{tabular}{|c|c|c|c|c|}
\hline Week & Module A & Module B & Presenter A & Presenter B \\
\hline 1 & Online communication & None & Instructor [Barnett] & \\
\hline 2 & Web 2.0 & None & Student [Sandieson] & \\
\hline 3 & Online collaboration & Online collaboration & Student B & Student C \\
\hline 4 & Online community & Internet safety & Student D & Student E \\
\hline 5 & Assessment & Online community & $\begin{array}{l}\text { Student } \\
\text { [McPherson] }\end{array}$ & Student G \\
\hline 6 & Time management & Time management & Student H & Student I \\
\hline 7 & $\begin{array}{l}\text { Second language } \\
\text { acquisition }\end{array}$ & Tablet computing & Student J & Student K \\
\hline 8 & Tablet computing & Exceptional children & Student L & Student M \\
\hline 9 & Academic dishonesty & Simulation & Student N & Student P \\
\hline 10 & At risk students & Academic dishonesty & Student Q & Student R \\
\hline
\end{tabular}

The instructor asked students to choose the modules in which they were most interested in participating without taking any module twice. They did this by self-selecting the combination of modules that they felt were most appropriate for their own learning goals. There were only two constraints, with the first limit being a maximum group size for each module. The instructor realized that to teach a module, a student acting as instructor would have to find at least some classmates in her or his group. The instructor limited the modules by group size so that every student instructor had a minimum number of their classmates participating in their respective modules. The second restriction was that no student could teach and/or participate in two modules on the same topic even though some topics appeared more than once. This check was to ensure a level playing field for module creation and participation. Students who signed up for one module could not see the materials nor the group discussion in the other module. The instructor arranged the modules as best as possible based on students e-mailed pre-course wish lists of learning.

The assessment consisted of thirty percent on the students' contributions to all the module discussions, thirty percent on the quality of the module that they taught and forty percent on a collaborative essay that 
they wrote with another student on a topic of their choosing that dealt with an important aspect of online education. Traditional assessment measures were put into place.

\section{Method}

After the completion of the course the co-researchers decided to study this course retrospectively, in the context that it might shed light on the possibilities of connectivist learning in institutional frameworks. Our goals in doing so were (a) to describe this particular course as a model of connectivism in itself, (b) to make inferences based upon our evolving understanding about connectivism as a learning model, and (c) to analyse the implications of this course as a learning model through the lens of our experiences in it. The research data in this paper come from a series of extended online synchronous text conversations amongst the co-researchers about connections to the course, related literature, classmates, each other and the online milieu itself.

In order to examine what happened, we critically questioned our perceptions of the design and implementation of this course in connectivist terms. However, as our data will show, connectivism, like constructivism before it, seemed to pose a disruptive epistemological challenge to the course. Thus, we also set out to question the theory in the context of the assumptions about knowledge and knowing that are inherent in the theory itself.

In order to create both trustworthiness and authenticity in the data collection, we decided to chat online with each other in a series of online conversations over the course of two months and these conversations would comprise the data collected. Each of us was to have equal voice. Statements made by every coresearcher would be open to challenge and meaning negotiation so that no matter what theoretical patterns might emerge from the conversations, a rigorous critical stance would be maintained throughout. As a group we also decided that conversations would be allowed to range widely while each conversation was monitored and facilitated by one of us in turn. This requirement meant that one of us had to wear two hats, so to speak, in every conversation.

Conversations ceased when we individually came to the view that we had covered every aspect of our experience of the course. This saturation occurred at the end of the ninth conversation. Each of the conversations lasted about one hour and together the conversations supplied all the data for the project. Without participants there was no need for member checking or for triangulation as such. Each researcher's understanding triangulated the views of the other researchers because, despite the negotiations of meaning in the online conversation, all coding was done individually, based on each researcher's individual unique understanding of the conversations.

After the data were collected, we each coded the data alone. Two of us coded data manually while one employed Atlas.ti, version 4.2. Each used the constant comparative method in creating our codes. As a final component of coding each co-researcher created a dictionary of our personally created codes. In other words, we each defined every one of our codes to explain what the code meant so that the others could better understand it. These dictionaries were invaluable in the next stage of analysis, code merging.

Using a wiki, we entered our codes and their definitions in turn. Then we incorporated our own codes into an emerging, combined list of codes. At this stage we had to rename and/or redefine various codes. Once we had come to a consensus that the list of codes could fully and fairly represent our joint understanding of the course experience, we re-coded the data using the merged code list. Finally, we analysed the data using the final codes and their definitions.

\section{Data analysis}

There were 86 codes in the merged code list and they were easily grouped around five main ideas: learning theory; course content, context or process; student experience; instruction; and conducting research. Since our purpose here is not to discuss the methodology, we do analyze the codes that dealt with the processes of conducting research in this paper.

One of the first and most obvious patterns that stood out from the code list itself was its similarity to Schwab's classic (1973) notion of the four commonplaces of curriculum: the learner, the teacher, the 
curriculum and the milieu. Codes that relate to student experience coincide closely with Schwab's student; codes that refer to instruction match with teacher; codes that reference learning theory and course content link well to curriculum; and codes that name course processes and context are similar to the milieu. Since two of the co-researchers had not heard about, nor read, Schwab's work prior to coding, we thought that the emergence of this pattern was significant.

The code list can also be argued as somewhat compatible with Barnett and Hodson's (2001) notion of pedagogical context knowledge composed of four areas: subject matter knowledge (course content), PCK (instruction), professional knowledge (learning theory) and classroom knowledge (course context and processes).

\section{Discussion}

(Please note that all quotations / data are from online synchronous chats and have not been edited for typographical or grammatical errors.)

\section{Course content and context}

The conversation started with the TVW course and its origins. Barnett had experience in teaching courses online and McPherson asked if this particular course was his since its inception. While it was not, it was similar to other courses he had taught; [Barnett]: "Those courses were discussion-based with lots of text and links. Yes they were not the same in that there was little student input into the content of the courses." (June 14, 2011) Sandieson asked, "Was the lack of student input in the previous course one of the reasons you decided to do the course that we took differently?" (June 14, 2011) Barnett replied, "It always seemed to me that I believed in constructivism and the online area allowed it to take place more naturally." He went on, "Well I have come to believe that a group of people always know more than any one person so I have been always wanting (sic) to help students have more ownership and at the same time learn how to teach online." Finally, "... [the course] is experiential, students experience the course as doing the course." (June 14, 2011). More to the point, he said, "I think we all are teachers in one way or another... and today with social networking the ability to help others is a form of teaching even if it is about teaching someone how to get past a certain level of a computer game." (June 14, 2011)

McPherson summed up the course, "So one might identify two different aspects about this course - the online medium itself, and then the fact that the course is about online learning.... One is of topical interest, the other, of modal accessibility." (June 30, 2011)

Sandieson asked what sort of planning went into the course. Barnett replied:

There was so much planning, Rachel, the first was the calendar of topics and with 17 people in the course I wanted to ensure that discussion groups would not be too large and that each student have a module to create and moderate... so getting the topics was a lot of emails back and forth... not only that but there were a lot of questions... and a lot of students needed to be reassured that they could indeed do it. (June 14, 2011)

Yet there were other problems [Barnett]:

Well they saw the lack of a plan not the parts that had already been done... and many were apprehensive... some didn't answer their messages.... I was waiting to hear back to organize it and then in the end [I] just assigned people to topics that others had chosen, therefore we had quite a few topics in which there were two groups... the responses also included the need for structure and to my surprise... one student put all the information together and created the calendar [of topics and student responsibilities]. (Please see Table 1) (June 14, 2011)

Sandieson noted, "I guess some people are just so used to courses having such a structure in place!" (June 14, 2011) One motivating factor to take such a course was [Sandieson], "...the flexibility of online courses ..." (June 14, 2011). The researcher students felt other students were disconcerted about this course because of its innovative organization. Perhaps, Sandieson suggested, it could work better if the 
course was more like others with which they had prior experience, "online in environment but they have a regularly scheduled class time.... Or a split of online and F2F." (June 30, 2011) McPherson concurred, "...an interesting hybrid of synchronicity / asynchronicity" although he was not convinced, "I don't know how well I like it. It's context dependent - at VHS [where I work], we never have anything scheduled, allowing the student maximum flexibility. But they can start on any day of the year, and finish on any day of the year, so it's a little different." (June 30, 2011)

\section{Student experience}

The two co-researchers who were student participants in the course described their initial feelings. Sandieson asked McPherson about his, [McPherson] "I was very excited, Rachel. This struck me as exactly my type of thing. But I confess that it was easier because I had had John as a teacher before." (June 14, 2011). Sandieson concurred, "I agree with Vance's comment. I had also worked with John before and I knew that for him, the journey is just as important as the final destination." (June 14, 2011)

She went on to describe her overall impressions:

I felt that I was more at home in this course than any other course I've taken in the faculty. Because I'm not a teacher, I always felt out of place in some of the other courses. I was able to bring more of my personal experience into this course in comparison to others. (June 14, 2011)

Perhaps because of its connectivist nature Sandieson thought that:

we all felt as though our voices were heard, no matter what our backgrounds were. The faculty is so diverse and this course really seemed to celebrate that, rather than focus solely on K-12 education. (June 14, 2011)

As with many online courses the two found that the course was much more time consuming than they expected, [McPherson]:

I likely put in, week for week, more time in this course than any other I've taken... certainly as much. But it didn't feel like it. I got excited about going to the library or The Docks or the Black Dog to get reading and writing. I closed down the buildings before I was done. (June 16, 2011)

Sandieson suggested that its connectivist nature added to the time commitment, "I didn't know what to expect; I had never been in a course like that before. I think I under-estimated the amount of work that would have to go into delivering the module and moderating the discussion." (June 16, 2011)

The two co-researchers also described more fully what it was like to have the role of instructor and moderator for their own topics. McPherson said, "Without anything but an internal frame of reference, I thought the A\&E [assessment and evaluation] discussion went very well. It was fractalinear; very branchy and spidery, but everything was connected and ordered. I can't say that I got a lot of feedback." (June 23, 2011)

Sandieson had a similar experience:

I honestly wasn't sure how my week went, even after it was finished. Since I was the first student moderator to go, I didn't know what things would be like in subsequent weeks; would people participate in other discussions more? Or less? So it wasn't until after a few weeks and seeing how it went for other people, that I really had an understanding for how my week went. (June 23, 2011)

There was no doubt it was a real challenge, [McPherson] "The most popular threads were the most general ones - I think the most responded-to thread was started by someone other than myself, and it was simply titled 'assessment', and turned into a grab-bag. But each new set of ideas led to something else...." (June 23, 2011) 
Sandieson had similar views:

Vance, I know with my week, I felt as though the discussions were more broad than they were in the other weeks. Maybe it was the number of students, but I think it was that people were trying to figure out the basics of online learning. I felt as though a lot of the discussions in my week were off-topic and were about online learning in general, rather than web 2.0 specifically. (June 23, 2011)

The nature of discussion forums as conversation came up, [McPherson], "I felt like the really lively conversations were based on experience and opinion, and the researched points / papers kinda stalled." (June 30, 2011) Barnett replied, "I saw that too, but to me that was effort, and even if the person wasn't really 'getting' it they were trying and I am a sucker for those who try their best no matter their ability," (June 30, 2011) Sandieson agreed more with McPherson, "Yes, I can think of one person (I won't name names!) who I often thought was posting a lot, but I couldn't see much value in what they were posting." (June 30, 2011) McPherson created a possible rationale for the behaviour, "John, to elaborate, my impression (it is an impression) is that folks were more likely to write verbose, paper-sounding posts with references and so forth when they were uncertain what to write." (June 23, 2011) Sandieson agreed, "I agree, Vance. And people were more likely to share new articles, media, etc, if they had a background knowledge of the topic. If it was something they were interested in." (June 23, 2011)

\section{Instructor experience}

The course instructor [Barnett] experienced a very different teaching experience than any he had encountered before. The first was his perception of loss of control. He did not create the curriculum because that was created by the passions and interests of students. This loss of control was not absolute because he still had, and exercised, his power of student assessment.

As his co-researchers asked him about his experience, "John, where I'm leading with this is that in a 'pure' connectivist context, there could be potentially no teacher." [McPherson] (June, 23 2011) Barnett admitted that, "yes, it was hard to give up control" (June 23, 2011). He compared it to running a social networking group with some reservation, "... I think that the LinkedIn and Facebook groups are a little like that, no one is really in charge, but are they educational?"

Sandieson asked, "Did you have a plan for if it didn't work out at all?" Barnett replied, "No i (sic) didnt Rachel...although deep inside I knew I could jsut (sic) use my previous material and moderate as I had done in the past."

McPherson was also interested in probing the loss of power, "John, were you determined to let it go no matter what happened?" Barnett replied, "yes I really wanted to let go Vance... i (sic) really wanted to share power as much as I could so that students would get a sense of really teaching online..but when people went far astary (sic) it was worrying lol... and then again I was doing the evaluation as is required by [the university] so in the end I still had the power." When asked how he dealt with these situations, he said, "I had a few emails back nd (sic) forth to try to help those who seemed lost at sea."

McPherson asked, "Can you talk about any effects that devolving power had on your ego, your sense of self-worth, etc.? (If we can accept as the sub-text that we all have these demons and we either learn to control them or we don't)". Barnett seemed fairly unconcerned, "I am confident enough in my knowledge of online education that my ego was not at risk/ besides i (sic) have analyzed my courses before with outside researchers and I know that nothing is perfect."

Sandieson and McPherson talked about their perceptions of instructor expertise in connectivist courses. [McPherson]. "So to extrapolate from that, John (or Rachel) — is the implication here that running a course like this requires extensive expert knowledge? Or experience?" Sandieson replied, "Maybe not expert knowledge, but an understanding of how things in an online class work and what is expected of both the moderator and the discussion participants"

That led to the notions of institutional power underlying the structure. McPherson reflected, "I wonder how much institutional freedom you would need to pull off a class like this? Would you try this class, 
John, if you weren't tenured?" Barnett answered, "I would likely have done it anyway because I am committed to freedom of thought for my stduents (sic)."

\section{Connectivism as enacted learning theory}

Examination of the data showed that the course, although connectivist in intent, did not comply perfectly or perhaps even well with some connectivist principles. As one of the co-researchers [McPherson] said, "While behaviorism, cognitivism and constructivism all model learning as occurring within the locus of the individual brain, connectivism models it as occurring, concurrently with teaching, across a network, both of brains and artificial intelligences/memories. (July 7, 2011)

Sandieson had a more pragmatic approach to connectivism, "For me, it's that learning doesn't just come from one person; so it's not the traditional model of the teacher passing on knowledge to the students. It's the whole group working together to create learning through participation." (July 7, 2011) In this definition, the course plan succeeded. The instructor did not create the modules, but had allowed those students with passion for a topic to create their own materials to share with the others. Indeed, some modules covered topics that the instructor knew little or nothing about.

The co-researcher [Barnett] who was the instructor took a pragmatic approach to the course design, "The connectivist approach in the course was to ask what students wanted to teach in their own modules and let that decide the curriculum... it was not perfect... [For example,] I thought Vance was really keen on assessment and I jumped the gun on him and that was not very connectivist." (July 7, 2011)

During the conversation he became aware that assigning students to modules based on his perceptions of their interests was not in line with, for lack of a better word, "pure" connectivism in which the group might together, as part of the course, define the curriculum.

There were other problems, Sandieson opined:

A drawback could be that sometimes the teacher really does possess all, or most of, the information. That is why they are in that position to begin with. It could be possible that the group is participating, but not really learning or getting anywhere new...Well, maybe more that some people who are "experts" are experts for a reason; teachers are in a position to pass on knowledge because they have extensive training, schooling, etc. So that top-down model may be better in certain circumstances. It is just a potential flaw of connectivism. (July 7, 2011)

In this, Sandieson clearly demarcated the tension between education as now commonly conceived and a more connectivist approach. It raised the important question of the role that expertise has to play in connectivist courses.

McPherson agreed, "It is what we've already discussed / discovered about moderators: they need to be there and visible (if not entirely trained) in this particular context. Which was an interesting and unfortunate find." (July 7, 2011) Sandieson and Barnett then exchanged views, [Sandieson], "So the difference for us was that we lead the discussions as moderators?" (July 7, 2011) [Barnett], "Not only did you lead the discussions Rachel but you decided what topics would be covered, that made it more connectivist I think." (July 7, 2011)

In other words, to define a connectivist course is to look at its design and also its execution. If one takes connectivism to its logical end point, as a democratic network of learning, then it cannot work without some intervention if it is to have a defined purpose even if that intervention is, as McPherson said, "... quite independent of expert knowledge or experience." (July 7, 2011) 


\section{Conclusion}

It was interesting to see that a very early theoretical framework of education, Schwab's commonplaces of curriculum, emerged from the data. In some ways, perhaps one could say that the more things change, the more they stay the same. The only difference between the course and the kinds of education that Schwab's original model described was that of milieu. The milieu, or context of the course, was not the classroom but rather the virtual landscape. Additionally, the instructor role merged with learner in a more democratic way than is usually the case. Finally, the data embodied Schwab's view that none of the components were the actual centre of the educational process. All were simply nodes in the network.

The course itself aspired to be connectivist. Although the instructor designed and developed almost all aspects of the course, he shared power for content definition and creation as well as course moderation with the students enrolled in the course. He modelled in the first module what he asked the students to do later in their own modules that they taught to their peers, fulfilling Downes's (2012b) axiom that, from a connectivist perspective, "to teach is to model and to demonstrate."

The experience displayed other connectivist features. Students with particular knowledge or passion for a topic were often the ones who created the background materials and moderated the discussions. Their modules often included multiple links to the literature as well as to informal sources. The sharing of choice in topics to teach was connectivist in essence because the entire group had some say in the course's curriculum. However, the ability for individuals to choose topics to take was not necessarily connectivist. To make the course more connectivist, the students and instructor could debate the topics that were included and collectively negotiate which individuals will teach them based on the number and value of their connections to that topic. Another way to make the course more connectivist would be to share and summarize amongst the entire group all the connections made in the topics. Finally, the course could include a mechanism to carry on after the formal course ended so that those who participated could continue as a learning community until such time as they decided to end it.

Like the MOOCs that specifically employ a connectivist pedagogy, the network principles of diversity, autonomy, openness, and emergent knowledge were compromised (Mackness, Mak, \& Williams, 2010). Despite the lack of "pure" connectivism, the two co-researchers who were students in the course felt more empowered and freer in the course than in other courses they had taken, despite the many challenges it posed for them.

While there is still a far way to go before this, or arguably any, online course is truly connectivist, this course was an example of a good first step. Instructors of online courses can see from this example how giving up some of their control can lead to more learning for their students. Taking advantage of new technologies and utilizing them in new ways is better than just trying to teach "traditional" courses online. The implications of connectivism in online learning and in this class in particular, are very broad and hopefully can lead to new kinds of courses and perhaps, new kinds of learning altogether.

\section{References}

Anderson, T., \& Dron, J. (2011). Three generations of distance education pedagogy. International Review of Research in Open and Distance Learning, 12(3), 80-97. Retrieved from http://www.irrodl.org/index.php/irrodl/article/view/890/1663

Barnett, J., \& Hodson, D. (2001) Pedagogical context knowledge: Toward a fuller understanding of what good science teachers know. Science Education, 85(4):426-453.

Bell, F. (2011). Connectivism: Its place in theory-informed research and innovation in technologyenabled learning. International Review of Research in Open and Distance Learning, 12(3), 98-118.

Bereiter, C. (1991). Implications of connectionism for thinking about rules. Educational Researcher, 20(3), 10-16. 
Cormier, D. (2008). Rhizomatic education: Community as curriculum. Innovate, 4(5). Retrieved from http://www.innovateonline.info/index.php?view=article\&id=550.

Downes, S. (2007). What connectivism is [Web log post]. Retrieved from Half an Hour http://halfanhour.blogspot.co.uk/2007/02/what-connectivism-is.html

Downes, S. (2012a). Connectivism and connective knowledge: Essays on meaning and learning networks. National Research Council (Canada). ISBN: 978-1-105-77846-9.

Downes, S. (2012b). Connectivism as epistemology. Half an Hour [Web log post]. Retrieved from http://halfanhour.blogspot.co.uk/2012/06/connectivism-as-epistemology.html

Dunaway, M. K. (2011). Connectivism: learning theory, and pedagogical practice for networked information landscapes. Reference Services Review, 39(4), 675-685. doi:10.1108/00907321111186686

Fenwick, T. J. (2010). (un)Doing standards in education with actor-network theory. Journal of Education Policy, 25(2), 117-133.

Garrison, D. R., \& Vaughan, N. D. (2008). Blended learning in higher education: Framework, principles, and guidelines. San Francisco: Jossey-Bass.

Gorman, M. J. (2001). The elusive origins of the immutable mobile. Unpublished paper. Stanford University. Retrieved from http://www.stanford.edu/group/STS/immutablemobile.htm

Granovetter, M. (1983). The strength of weak ties: a network theory revisited. Sociological Theory, 1, 201-233.

Hopfield, J. J. (1982). Neural networks and physical systems with emergent computational abilities. Proceedings of the National Academy of Sciences of the United States of America, 79, 2954-2958. Retrieved from http://www.pnas.org/content/79/8/2554.full.pdf+html

Ireland, T. (2007). Situating connectivism [Design Wiki]. ETEC 510: Design of technology-supported learning environments. University of British Columbia. Retrieved from: http://etec.ctlt.ubc.ca/510wiki/Situating_Connectivism

Koehler, M. J., \& Mishra, P. (2008). Introducing TPCK. In ACCTE Committee on Technology and Innovation (Eds.), Handbook of technological pedagogical content knowledge (TPCK) for educators (pp. 3-29). New York: Routledge/Taylor \& Francis Group.

Kop, R., \& Hill, A. (2008). Connectivism: Learning theory of the future or vestige of the past? International Review of Research in Open and Distance Learning, 9(3), 1-13.

Lave. J., \& Wenger, E. (1991). Situated learning: Legitimate peripheral participation. New York and Cambridge, UK: Cambridge University Press.

Levy, P. (1997). Collective intelligence: Mankind's emerging world in cyberspace (R. Bononno, Trans.). New York: Plenum.

Mackey, T., \& Jacobson, T. (2011). Reframing information literacy as metaliteracy. College and Research Libraries. 72(1), 62.

Mackness, J., Mak, S., \& Williams, R. (2010, May). The ideals and reality of participating in a MOOC. Paper presented at the Seventh International Conference on Networked Learning, Aalborg, Denmark.

Marcum, J. (2006). After the information age: A dynamic learning manifesto. New York: Peter Lang.

Mason, R. (1998). Models of online courses. ALN Magazine. 2(2). Retrieved from http://wwwusers.york.ac.uk/ ijc4/etutoring/week 1/Robin Mason paper.doc 
Rapaport, M. (1991). Computer mediated communications: Bulletin boards, computer conferencing, electronic mail, information retrieval. New York. John Wiley \& Sons.

Rolls, E. T. (2008).Memory, attention, and decision-making: A unifying computational neuroscience approach. Oxford: Oxford University Press.

Schwab, J. J. (1973). The practical 3: Translation into curriculum. School Review. 81(4), 501-522.

Schunk, D. H. (2004). Learning theories: An educational perspective. (4th ed.). Upper Saddle River, NJ: Pearson/ Merrill Prentice-Hall.

Sibani, P., \& Jensen, H. J. (2013). Stochastic dynamics of complex systems: From glasses to evolution. London, UK. Imperial College Press.

Siemens, G. (2005). Connectivism: Learning as network-creation [Web log post].

Retrieved from Elearnspace http://www.elearnspace.org/Articles/networks.htm

Siemens, G. (2010). Teaching in a social and technological network [Web log post]. Retrieved from Connectivism http://www.connectivism.ca/?p=220

Slavich, G. M., \& Zimbardo, P. G. (2012). Transformational teaching: Theoretical underpinnings, basic principles, and core methods. Educational Psychology Review, 24(4), 569-608.

Smith, J. B. (1995). Collective intelligence in computer-based collaboration. Hillsdale, NJ: Lawrence Erlbaum.

Spitzer, M. (1999). The mind within the net: Models of learning, thinking, and acting. Cambridge, MA. MIT Press.

Tschofen, C., \& Mackness, J. (2012). Connectivism and dimensions of individual experience. International Review of Research in Open and Distance Learning, 13(1), 124-143. Retrieved from http://www.irrodl.org/index.php/irrodl/article/view/1143/2117

Wade, M. C. (2012). A critique of connectivism as a learning theory [Web log post]. Retrieved from Cybergogue: Doing is Learning http://cybergogue.blogspot.nl/2012/05/critique-of-connectivism-aslearning.html

Corresponding author: John Barnett, barnett@uwo.ca

Australasian Journal of Educational Technology (C) 2013.

Please cite as: Barnett, J., McPherson, V., \& Sandieson, R. M. (2013). Connected teaching and learning: The uses and implications of connectivism in an online class. Australasian Journal of Educational Technology, 29(5), 685-698. 